\title{
Nutritional potential of bamboo leaves for feeding dairy cattle ${ }^{1}$
}

\author{
José Herilalao Andriarimalala ${ }^{2}$, Claude Cocou Kpomasse ${ }^{3}$, \\ Paulo Salgado ${ }^{4}$, Noroseheno Ralisoa ${ }^{2}$ Jayraman Durai $^{5}$
}

\section{ABSTRACT}

Feed shortage during the dry season in the highlands of Madagascar negatively impacts the dairy cattle productivity, as well as the farmers' income. Bamboo can produce a high quantity of biomass and could be an alternative way to increase the fodder supply for cattle. The present study aimed to assess the compositional information and the optimal rate of bamboo as fodder for dairy cattle. Leaf samples from nine bamboo species were collected to determine their chemical composition and nutritive value. A feeding experiment was also conducted using ten dairy cows, over ten weeks. Bamboo leaves were mixed with maize silage in five proportions: SIL0:BAM100, SIL25:BAM75, SIL50:BAM50, SIL 75:BAM25 and SIL100:BAM0. The contents of dry matter, total ash and crude protein in the bamboo leaves were, respectively, 44.5-64.6\%, 6.68-18.5\% and 7.71$15.4 \%$. In the feeding trial, the dry matter intake of bamboo leaves was 1.6-7.1 kg per day, with an average of $4.8 \mathrm{~kg}$ per day. The dry matter apparent digestibility of bamboo leaves was 37.4-56.4\%. The milk production reached 13.6-14.4 L per cow, per day, but there was no significant difference concerning the rate of bamboo leaves in the mixed diet $(p>0.05)$. The introduction of bamboo leaves into the ruminants diet did not affect their milk production.

KEYWORDS: Fodder, in vivo digestibility, woody grass.

\section{INTRODUCTION}

To meet the increasing global food demand, it is necessary both to increase the productivity and to use available resources more efficiently. Family farmers constitute approximately $60 \%$ of the global agricultural production (FAO 2016). Around $98 \%$ of farms in the world are family farms that are heavily

\section{RESUMO}

Potencial nutritivo de folhas de bambu na alimentação de gado leiteiro

A escassez de alimentos durante a estação seca nas terras altas de Madagascar causa impactos negativos à produtividade do gado leiteiro e aos rendimentos dos agricultores. $\mathrm{O}$ bambu pode produzir elevada quantidade de biomassa e ser uma alternativa para aumentar a oferta de forragem para o gado. Objetivou-se avaliar a composição, bem como a taxa ótima, de bambu como forragem para gado leiteiro. Amostras de folhas de nove espécies de bambu foram colhidas para determinar a sua composição química e valor nutritivo. Um ensaio de alimentação também foi conduzido com dez vacas leiteiras, durante dez semanas. As folhas de bambu foram misturadas com silagem de milho, em cinco proporções: SIL0:BAM100, SIL25:BAM75, SIL50:BAM50, SIL 75:BAM25 e SIL100:BAM0. Os teores de matéria seca, cinza total e proteína bruta das folhas de bambu foram, respectivamente, $44,5-64,6 \%, 6,68-18,5 \%$ e 7,71-15,4\%. No teste de alimentação, o consumo de matéria seca das folhas de bambu foi de 1,6-7,1 kg por dia, com média de 4,8 kg por dia. Adigestibilidade aparente da matéria seca das folhas de bambu foi de 37,4-56,4\%. A produção de leite alcançou 13,6-14,4 L por vaca, por dia, mas não houve diferença significativa em função da proporção de folhas de bambu na dieta mista $(p>0,05)$. A introdução de folhas de bambu na dieta dos ruminantes não afetou a produção de leite.

PALAVRAS-CHAVE: Forragem, digestibilidade in vivo, grama lenhosa.

dependent on natural resources for their subsistence (Bergeret et al. 2016). However, the scarcity of resources does not allow for increasing the agricultural production, leading to a vulnerability of the global population to food insecurity and hunger (FAO 2016). Agriculture contributes with $20 \%$ of the Madagascar's gross domestic product and involves $74 \%$ of the working population (World Bank 2019).

1. Received: Aug. 10, 2018. Accepted: Feb. 15, 2019. Published: Apr. 03, 2019. DOI: 10.1590/1983-40632019v4954370.

2. Fiompiana Fambolena Malagasy Norveziana (Fifamanor), Centre de Développement Rural et de Recherche Appliquée, Antsirabe, Madagascar. Email/ORCID: andriari.jose@gmail.com/0000-0001-7421-1589, ralisoo@yahoo.fr/0000-0002-8960-9140.

3. Université d'Abomey-Calavi, Cotonou, Benim. Email/ORCID: claudez1984@yahoo.fr/0000-0002-2760-546X.

4. Centre de Coopération Internationale en Recherche Agronomique pour le Développement (CIRAD), Antsirabe, Madagascar. Email/ORCID: paulo.salgado@cirad.fr/0000-0003-1815-6604.

5. International Network for Bamboo and Rattan (INBAR), Beijing, China. Email/ORCID: jdurai@inbar.int/0000-0003-4563-4501. 
Around half of the famers in the highlands have a regular income based on dairy farming (Fofifa 2018). More than $80 \%$ of the milk is produced in the Vakinankaratra region, in mixed farms with less than five cows and a low individual average of 2,600 $\mathrm{L} \mathrm{cow}^{-1}$ year ${ }^{-1}$ (Penot et al. 2016). The low milk productivity is mainly due to feed shortage, especially fodder. Fodder deficit is very intense during the dry season, from April to November. During this period, the natural pastures and crop residues are the main feed for ruminants. However, these resources are not suitable for dairy cattle feeding, as they are often high in fibre content and low in most essential nutrients, including protein, energy, minerals and vitamins that are required for rumen microbial fermentation (Asaolu et al. 2009). Therefore, this inhibits the productivity, health, body condition and reproduction of genetically improved dairy cattle.

Bamboo species are integral components of agroecosystems from the highlands to the coastal areas in the east and west of Madagascar. They can also be grown on a variety of soil types and are a fast growing plant species. Bamboo is commonly used for feeding humans and animals, fuel, pharmaceuticals, building materials and chemicals, and is also applied to environmental purposes, such as erosion control and carbon sequestration (Halvorson et al. 2010). Research has been conducted on the use of bamboo leaves as fodder for several animal species, including cattle, sheep and goats (Hayashi et al. 2005, Asaolu et al. 2009, Halvorson et al. 2010), in many Asian and African countries. However, bamboo leaves have not been investigated as a fodder resource for dairy cattle in Madagascar, and information about their nutritive value is limited. The use of bamboo leaves as fodder in several developing countries needs to be further developed and tested (Antwi-Boasiko et al. 2011, INBAR 2019).

Due to its fast growth, high biomass production and wide adaptability of green leaves during winter months, bamboo can be an alternative source of fodder for dairy cattle and maintain their milk production during the dry season. The present study was carried out to assess the compositional information, as well as the optimal rate, of bamboo species as fodder for dairy cattle.

\section{MATERIAL AND METHODS}

The study was conducted at the Fiompiana Fambolena Malagasy Norveziana (Fifamanor), or
Rural Development and Applied Research Centre in Agriculture and Livestock, in Antsirabe, Madagascar ( $19^{\circ} 48^{\prime} \mathrm{S}, 47^{\circ} 07^{\prime} \mathrm{E}$ and altitude of 1,600 m), from May to November 2017, which coincided with the dry season in the highlands of Madagascar. The location has a tropical altitude climate, with an average temperature of $17^{\circ} \mathrm{C}$ and annual average rainfall of $1,300 \mathrm{~mm}$.

Twenty samples of bamboo leaves were collected in five regions of Madagascar (central region: Analamanga and Itasy; eastern region: Vatovavy Fitovinany and Atsinanana; and north region: Sofia). These samples belonged to nine different species: Bambusa balcooa, Bambusa bambos, Bambusa vulgaris, Bambusa tulda, Dendrocalamus asper, Dendrocalamus giganteus, Dendrocalamus strictus, Phyllostachys aurea and Gigantochloa pseudoarundinacea. About $2.0 \mathrm{~kg}$ of representative samples of fresh bamboo leaves were collected, packed in air tight bags and transported to the laboratory for further analyses.

At the laboratory, all bamboo leaf samples were finely chopped and dried in a hot air oven at $60{ }^{\circ} \mathrm{C}$, for $72 \mathrm{~h}$. Then, they were ground using a hammer mill to pass a $1 \mathrm{~mm}$ screen and analyzed using wet chemistry (AOAC 1995). The quantity of residual dry matter was determined after drying in a hot air oven at $105^{\circ} \mathrm{C}$, for $8 \mathrm{~h}$. Total ash was analyzed by incineration at $550^{\circ} \mathrm{C}$, for $8 \mathrm{~h}$, in a muffle furnace. Crude protein was determined using the Kjeldahl method (Shaw 2006). The crude fibre content was obtained by incineration after acid and base digestion. Neutral detergent fibre and acid detergent fibre were determined using the procedures of Goering \& Van Soest (1970). Acid detergent lignin was evaluated by subjecting acid detergent fibre residue to $72 \%$ sulphuric acid. Cow faecal samples were dried in an air oven at $60^{\circ} \mathrm{C}$, for $72 \mathrm{~h}$.

Ten Norwegian Red Pied cows at first lactation, with a mean body weight of $417 \pm 25 \mathrm{~kg}$, were used during the experiment. The cows were selected and divided into five groups by balancing the milk amount, length of lactation and body weight. The experimental design was a $5 \times 5$ Latin square, with five treatments and five groups of animals. The five treatments comprised a control group, which was not receiving bamboo leaves in its diet and was compared to four experimental groups consuming, respectively, $25 \%, 50 \%, 75 \%$ and $100 \%$ of bamboo leaves in their diet. The groups of animals were interchanged 
across the different treatments every two weeks, including four days of adaptation and ten days of data collection. The total duration of the trial was ten weeks.

The amount of feed offered to each animal was calculated on the assumption that one animal can consume $3.0 \mathrm{~kg}$ of dry matter of forage per $100 \mathrm{~kg}$ of body weight per day. This amount was constant throughout the study and was distributed to each animal in two equal feeds at $07.00 \mathrm{a} . \mathrm{m}$. and 4.00 p.m. Refusals from the previous days feeding were weighed every morning, before the new feeding, to allow the calculation of the daily intake.

Faeces of each animal were collected at 07.00 a.m. and 03.00 p.m. each day and weighed. In order to measure the dry matter apparent digestibility, about $500 \mathrm{~g}$ of faecal sample were collected per day, per animal, and analyzed.

The dry matter apparent digestibility was calculated as [(intake - faeces)/intake] $* 100$.

The amount of milk produced by each cow was measured at 07.00 a.m. and 03.00 p.m.

The daily ration was composed of maize silage, bamboo leaves and concentrate feed (Table 1). Bambusa vulgaris and Dendrocalamus giganteus leaves were collected by cutting them at the stem level, in the eastern region of Madagascar, and transported weekly to the research centre. Maize was planted and ensiled at Fifamanor. To establish the diet, the two collected varieties of bamboo leaves were mixed each week to create a single ration of bamboo leaves. The raw bamboo leaves were then mixed with maize silage, according to the different proportions in the treatments, on the basis of the dry matter content. Cows in group 2 received $75 \%$ of maize silage and $25 \%$ of bamboo leaves (SIL75:BAM25). Those in group 3 consumed equally maize silage and bamboo leaves (SIL50:BAM50). Those in group 4 received $25 \%$ of maize silage and $75 \%$ of bamboo leaves (SIL25:BAM75). Cows in group 1 were offered an unrestricted sole diet of maize silage (SIL100:BAM0), while those in group 5 received an unrestricted sole diet of bamboo leaves (SIL0:BAM100). Each cow received $4.0 \mathrm{~kg}$ of concentrate feed per day, during the trial. The concentrate feed composition was different for each treatment, in order to balance the nutritional intakes of the diets by using the Inration software, version 3.3 (Table 2). Fresh and clean water was available ad libitum to the animals throughout the duration of the trial.

The statistical analysis used a one-way analysis of variance (Anova) for the data treatment, after processing the Shapiro-Wilk normality and Levene's variance homogeneity tests. Data were analyzed using the XLStat software, version 2008 6.03, copyright Addinsoft 1995-2008. A level of $\mathrm{p}<0.05$ was chosen as the minimum for testing the significance. Significant differences between means were compared using the Tukey test.

\section{RESULTS AND DISCUSSION}

The proximate compositions of sampled bamboo leaves are presented in Table 3.

The dry matter content ranged from $44.5 \%$ in $D$. asper to $64.6 \%$ in $P$. aurea, averaging $57.1 \%$; total ash from $6.68 \%$ in B. bambos to $18.5 \%$ in $D$. strictus, averaging $13.5 \%$; crude fibre from $25.9 \%$ in D. strictus to $32.6 \%$ in D. asper, with an overall mean of $29.1 \%$; and crude protein from $7.71 \%$ in B. balcooa to $15.4 \%$ in B. bambos, with an average of $12.5 \%$. The mean values for neutral detergent fibre, acid detergent fibre and acid detergent lignin across the species were, respectively, $76.2 \%, 51.5 \%$ and $12.1 \%$. P. aurea had the highest $(79.3 \%)$ neutral detergent fibre level, while D. giganteus had the lowest $(72.4 \%)$ one. The lowest content of acid detergent fibre was recorded in P. aurea $(43.8 \%)$ and the highest one in G. pseudoarundinacea (55.1\%). A small variation across the species from $10.4 \%$

Table 1. Nutritive value of mixed forage per treatment.

\begin{tabular}{lcccrr}
\hline \multicolumn{1}{c}{ Nutritive value } & SIL0:BAM100 & SIL25:BAM75 & SIL50:BAM50 & SIL75:BAM25 & SIL100:BAM0 \\
\hline DM \% & 57.50 & 52.10 & 46.80 & 41.50 & 36.10 \\
FUL (unit/kg DM) & 0.43 & 0.54 & 0.67 & 0.78 & 0.90 \\
CP (g/kg DM) & 121.00 & 111.00 & 101.00 & 91.80 & 82.10 \\
RBP (g/kg DM) & 43.70 & 45.90 & 48.20 & 50.40 & 52.60 \\
\hline
\end{tabular}

BAM: bamboo leaves; CP: crude protein; DM: dry matter; FUL: feed unit for lactation; RBP: rumen bypass protein; SIL: maize silage. The FUL unit corresponds to the amount of energy value in a feed and is obtained by finding the ratio of the net energy of the feed to the net energy provided by $1 \mathrm{~kg}$ of barley dry matter (1,700 kcal of net energy $/ \mathrm{kg}$ of dry matter). 
Table 2. Composition and nutritive value of concentrate feed per treatment.

\begin{tabular}{lccrrr}
\hline Ingredients & SIL0:BAM100 & SIL25:BAM75 & SIL50:BAM50 & SIL75:BAM25 & SIL100:BAM0 \\
\hline Maize (\%) & 85.00 & 81.00 & 77.00 & 75.00 & 72.00 \\
Peanut cake (\%) & 12.00 & 16.00 & 20.00 & 22.00 & 25.00 \\
Salt (\%) & 0.75 & 0.75 & 0.75 & 0.75 & 0.75 \\
Shell powder (\%) & 2.00 & 2.00 & 2.00 & 2.00 & 2.00 \\
MVS (\%) & 0.25 & 0.25 & 0.25 & 0.25 & 0.25 \\
\hline Nutritive value & & & & 89.70 & 90.00 \\
\hline DM (\%) & 89.20 & 89.30 & 89.50 & 1.09 & 1.09 \\
FUL (unit/kg DM) & 1.08 & 1.08 & 1.09 & 157.00 & 157.00 \\
CP (g/kg DM) & 154.00 & 155.00 & 101.00 & 103.00 & 103.00 \\
RBP (g/kg DM) & 100.00 & 101.00 & & & \\
\hline BAM b & & & & & \\
\hline
\end{tabular}

BAM: bamboo leaves; CP: crude protein; DM: dry matter; FUL: food unit for lactation; MVS: mineral and vitamin supplements; RBP: rumen bypass protein; SIL: maize silage.

Table 3. Chemical composition of bamboo leaves.

\begin{tabular}{lccccccc}
\hline \multirow{2}{*}{ Bamboo species } & DM & Ash & CF & CP & ADF & ADL & NDF \\
\cline { 2 - 6 } & & & & & \% DM & & \\
Bambusa balcooa & 58.50 & 17.10 & 28.00 & 7.71 & 53.90 & 11.50 & 77.90 \\
Bambusa bambos & 57.20 & 6.68 & 26.30 & 15.40 & 49.10 & 14.40 & 75.70 \\
Bambusa tulda & 57.10 & 10.90 & 31.80 & 13.40 & 53.90 & 15.20 & 76.60 \\
Bambusa vulgaris & 57.10 & 16.10 & 27.00 & 15.00 & 54.30 & 12.30 & 76.60 \\
Dendrocalamus asper & 44.50 & 11.30 & 32.60 & 11.80 & 50.90 & 11.20 & 74.70 \\
Dendrocalamus giganteus & 52.70 & 12.20 & 29.20 & 14.30 & 50.50 & 10.60 & 72.40 \\
Dendrocalamus strictus & 59.80 & 18.50 & 25.90 & 10.70 & 51.60 & 10.40 & 74.30 \\
Phyllostachys aurea & 64.60 & 11.00 & 28.90 & 11.60 & 43.80 & 10.60 & 79.30 \\
Gigantochloa pseudoarundinacea & 61.90 & 17.50 & 32.00 & 12.90 & 55.10 & 12.80 & 78.50 \\
\hline Mean & 57.10 & 13.50 & 29.10 & 12.50 & 51.50 & 12.10 & 76.20 \\
\hline SD & 5.79 & 3.98 & 2.56 & 2.41 & 3.52 & 1.72 & 2.21 \\
\hline
\end{tabular}

ADF: acid detergent fibre; ADL: acid detergent lignin; CF: crude fibre; CP: crude protein; DM: dry matter; NDF: neutral detergent fibre; SD: standard deviation.

(D. strictus) to $15.2 \%$ (B. tulda) was observed in the acid detergent lignin content.

The dry matter values obtained in the present study were comparable with those for bamboo in India (Bhandari et al. 2015), which ranged from $45.2 \%$ to $65.4 \%$, averaging $54.2 \%$, in leaves of B. bambos, B. balcooa, B. multiplex, B. nutans, B. tulda, B. vulgaris, D. giganteus, D. hamiltonii, D. longispathus, D. membranaceus, D. strictus, Gigantochloa albociliata, Melacanna baccifera and Pseudoxytenanthera stocksii. In general, fodder species containing more than $30 \%$ of dry matter and having $50 \%$ of organic matter digestibility and less than $10 \%$ of total ash content are considered a good fodder (Bhandari et al. 2015). A dry matter content of fresh fodder less than $15 \%$ may restrict the voluntary intake in ruminants, as a higher water content within the plant cell causes bulkiness in the feeds (Tinworth et al. 1999).
The mean values for dry matter content in the bamboo species analyzed in the present study were well above $15 \%$. The total ash content is considered a good criterion of the total mineral content of the plant material. Excluding B. bambos, which had a total ash content of less than $10 \%$, the mean total ash content of all bamboo species was $14 \%$, which is considered acceptable.

Bhandari et al. (2015) reported crude protein contents of bamboo leaves averaging $12.3 \%$ and ranging from $8.4 \%$ to $17.1 \%$, which are comparable to our results. B. balcooa showed a particularly low crude protein content (less than $10 \%$ ), which is considered a poor quality feed, in terms of protein. Indeed, below this level, the rumen fermentation is adversely affected (Norton 2003, Bhandari et al. 2015). A good fodder for dairy cattle needs around $18 \%$ of crude protein, less than $30 \%$ of acid detergent fibre and less than $40 \%$ of neutral detergent 
fibre. Fodder is considered low grade if the crude protein content is less than $8 \%$, acid detergent fibre is more than $45 \%$ and neutral detergent fibre content is more than $65 \%$ (Upreti \& Shrestha 2006). B. bambos presented more than $15 \%$ of crude protein content and was considered a good fodder. The other species had crude protein values between $10 \%$ and $15 \%$ and were considered to be of moderate quality. The use of forage resources that are rich in crude protein enabled reducing the concentrate feed in the ruminant diet, thus reducing the milk production cost.

The crude fibre measurements obtained in the present study are comparable to those reported by Bhandari et al. (2015), which ranged from $20.7 \%$ to $45.9 \%$ and averaged $26.5 \%$. Crude fibre is a measure of the quantity of feed indigestible components and has little nutritive value, but provides the bulk necessary for a proper peristaltic action in the intestinal tract and is important for maintaining the rumen health (McDonald et al. 2010, Bhardwaj et al. 2018). The higher the crude fibre content, the more indigestible the fodder will be, as it contains more lignin, a non-nutrient component. Indeed, lignin can be associated with polysaccharides and proteins, particularly in shrubs, making it difficult for rumen microbes to enzymatically degrade it. Only $30 \%$ of the analyzed bamboo species contained crude fibre content above $30 \%$, what may be due to the maturity of the bamboo leaves, as the crude fibre content increases with the age and maturity of the plant species (Anele et al. 2008).

The measurement range of neutral detergent fibre was narrow, if compared to that reported by Bhandari et al. (2015), which varied from $61.7 \%$ to $80.9 \%$, averaging $68.1 \%$. Neutral detergent fibre includes hemicellulose, cellulose, lignin, heat damaged protein and silica. It is strongly related to the feed voluntary intake and the availability of net energy from digestible energy (Bhandari et al. 2015). Generally, the neutral detergent fibre content of a fodder should be more than $25 \%$ or $30 \%$ (Upreti \& Shrestha 2006). However, all the species analyzed had neutral detergent fibre contents over $70 \%$, and so were considered poor-quality fodder, in terms of fibre.

The acid detergent fibre contents of the bamboo species in the present study were comparable to those reported by Bhandari et al. (2015), which ranged from $41.3 \%$ to $50.6 \%$ and averaged $46.4 \%$. A higher value of acid detergent fibre represents a lower digestibility. Indeed, the digestibility of plant walls is strongly influenced by cellulose and lignin concentrations. These results confirm that the bamboo species available in Madagascar have a potential as fodder for ruminants. The high quantity of crude protein in the leaves of these bamboo species suggests that they are a good source of nitrogen supplement for ruminants that feed on poor-quality grasses and crop residues with low protein content, especially during the dry season. On average, the analyzed bamboo leaves had lower contents of protein than Lolium multiflorum (20\% of crude protein) and Avena sativa ( $15 \%$ of crude protein), which are commonly planted and used during the dry season by farmers (Fifamanor 2009). The nutritive value of bamboo leaves was much better than that of crop residues such as rice straw (on average, $5 \%$ of crude protein and $35 \%$ of crude fibre), which is commonly fed to ruminants during this season.

The determination of the nutritional quality of bamboo leaves is an important aspect of ruminant feeding and a step towards creating a balanced diet (Bhandari et al.2015). The knowledge of the nutritional potential of bamboo leaves in dairy cattle feeding will increase the adoption of these multipurpose resources by farmers. Bamboo leaves can provide an important component for ruminants diets and enable the maintainance of the animal performance throughout the year, especially during seasons of fodder shortage. However, it is also important to measure the nutrients intake and digestibility.

The dry matter intake of bamboo leaves was 1.6-7.1 kg of dry matter per day, with an average of $4.8 \mathrm{~kg}$ per day (Table 4$)$. The SIL 0:BAM100 treatment showed a significantly higher dry matter intake, while SIL 75:BAM25 had the lowest one $(p<0.05)$. The dry matter apparent digestibility in bamboo leaves was significantly higher for SIL50:BAM50, at $56.4 \%(\mathrm{p}<0.05)$. In contrast, the dry matter apparent digestibility was lower for SIL75:BAM25, at $37.4 \%$ $(\mathrm{p}<0.05)$. Concerning maize silage, the dry matter intake ranged from $2.1 \mathrm{~kg}$ per day to $8.5 \mathrm{~kg}$ per day, while the dry matter apparent digestibility ranged from $71.6 \%$ to $74.6 \%$. SIL100:BAM0 had a significantly higher value for dry matter intake than the other treatments, while the intake of SIL25:BAM75 was lower, if compared to the other treatments $(\mathrm{p}<0.05)$. Although the dry matter digestibility of maize silage was numerically higher in SIL50:BAM50, when compared to the other treatments, the differences were not significant $(\mathrm{p}>0.05)$. 
Table 4. Mean intake and apparent digestibility of bamboo leaves and maize silage per treatment.

\begin{tabular}{lccccrc}
\hline \multicolumn{1}{c}{ Parameters } & SIL0:BAM100 & SIL25:BAM75 & SIL50:BAM50 & SIL75:BAM25 & SIL100:BAM0 & $\mathrm{p}$ \\
\hline Intake BAM (kg DM per day) & $7.1 \mathrm{a}^{*}$ & $6.2 \mathrm{~b}$ & $4.4 \mathrm{c}$ & $1.6 \mathrm{~d}$ & - & $<0.05$ \\
Intake SIL (kg DM per day) & - & $2.1 \mathrm{~d}$ & $4.7 \mathrm{c}$ & $6.9 \mathrm{~b}$ & $8.5 \mathrm{a}$ & $<0.05$ \\
Digestibility BAM (\% DM) & $48.6 \mathrm{ab}$ & $53.6 \mathrm{a}$ & $56.4 \mathrm{a}$ & $37.4 \mathrm{~b}$ & - & $<0.05$ \\
Digestibility SIL (\% DM) & - & 71.9 & 74.6 & 73.5 & 71.6 & 0.47 \\
\hline * Means in the same row without common letters are different (p< $<0.05)$. BAM: bamboo leaves; DM: dry matter; $\mathrm{p}$ : p-value; SIL: maize silage.
\end{tabular}

* Means in the same row without common letters are different $(\mathrm{p}<0.05)$. BAM: bamboo leaves; DM: dry matter; $\mathrm{p}$ : $\mathrm{p}$-value; SIL: maize silage.

Intake values and the ingestion capacity of the animal determine its dry matter voluntary consumption. Generally, the intake of treatments where both bamboo and silage were offered (SIL25:BAM75, SIL50:BAM50 and SIL75:BAM25) were lower than those with single bamboo or silage (SIL0:BAM100 and SIL100:BAM0). The equal complementation of maize silage with bamboo leaves, which are rich in crude protein, was interesting, in terms of digestibility of both fodders. In contrast, the incorporation of $25 \%$ of bamboo leaves improved the dry matter intake and digestibility of maize silage to the detriment of bamboo leaves. Bamboo leaves fed to animals during the trial were relatively mature and had a high fibre content. The animals tended to choose the maize silage over bamboo leaves, in a mixed diet of both fodders. Indeed, maize silage had a good intake and was very readily consumed by the dairy cattle, perhaps because it was less fibrous and less bulky (Vignau-Loustau \& Huyghe 2008). The forage intake decreases with the age of the plants, as the proportions of stems, lignified tissues and cellwalls increase. In practice, a high fodder intake by animals can be achieved by harvesting plants at early stages. Hutjens (1998) also confirmed that roughage, which has higher contents of neutral detergent fibre, acid detergent fibre and acid detergent lignin, can restrict the consumption for ruminants.

Bamboo leaves and maize silage were nutritionally balanced and complementary. VignauLoustau \& Huyghe (2008) reported that silage is an unbalanced forage, that has a high energetic value but a lower nitrogen value, with a crude protein content of less than $10 \%$. It is important to identify the optimal stage and period to harvest bamboo leaves, in order to achieve a moderate fibre content and improve intake and digestibility.

The daily milk production of dairy cows in the feeding trial provides an indication of the production value of the different diets. Bamboo leaf consumption enabled cows to maintain the milk production during the period of forage shortage, which varied from 13.6 L to $14.4 \mathrm{~L}$ per cow, per day, but displayed no significant difference between treatments $(p>0.05$; Figure 1). SIL50:BAM50 showed the maximum milk production and SIL0:BAM100 the minimum one.

The incorporation of bamboo leaves into the basal diet of dairy cattle did not affect their milk production. Instead, bamboo leaves enabled the cows to achieve a milk production rate comparable to that seen with a sole diet of maize silage and concentrate feed. Bamboo provided an important constituent of daily rations for the ruminants (Datt et al. 2006, Bhandari et al. 2015). Among the available shrubs, bamboo can be exploited as forage, to reduce the fodder scarcity and feed ruminants and meet their nutritional requirements, especially during the dry season (Anurudu et al. 2004, Bhardwaj et al. 2018). The nutritional complementarity of maize silage and bamboo leaves could be leveraged in the daily ration of cows during the experiment. According to Delaby \& Peyraud (2009), the combination of fodder with maize silage is beneficial, in terms of milk production. The high protein and mineral contents of bamboo leaves complemented the high energy content and intake of maize silage. Maize silage is often fed with forage in rations to balance the energy

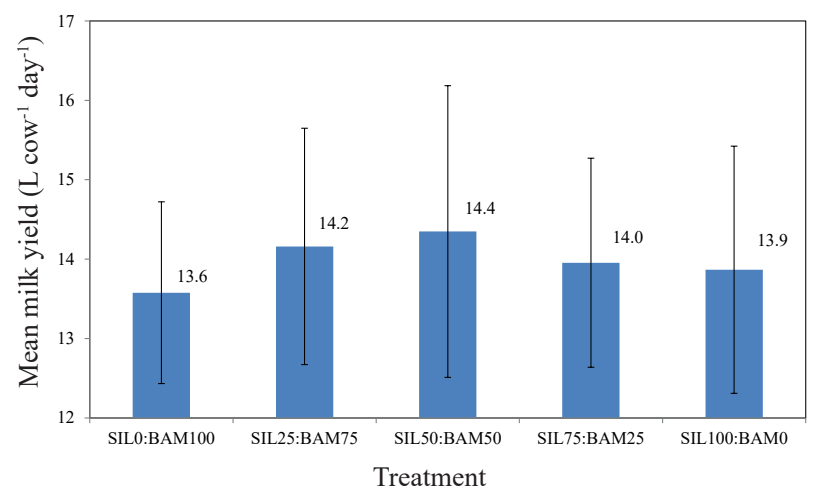

Figure 1. Mean milk yield per treatment. SIL: maize silage; BAM: bamboo leaves. 
and the protein in the diet, as well as to improve the digestion quality (Gauthier 2016, Férard \& Carel 2017). The diversity of forage species increases the forage availability and animal productivity in farms, ensuring the food security of farmers.

Furthermore, the collection and transport costs of bamboo leaves are not a constraint for farmers, especially if they are available close to the farms. Thus, the feed cost is reduced, improving the longterm viability and profitability of farms. At the time of harvesting bamboo culms for various uses, bamboo leaves can be recovered and fed to dairy cattle. Farmers can also integrate the bamboo cultivation to their forage system, in order to improve the feed sufficiency. Bamboo cultivation is also advantageous, in that it is a low input system and does not require irrigation. A thorough study including the effects of the harvesting stage of bamboo leaves, as well as the collecting season, on their chemical composition and nutritive value would identify the appropriate harvesting time for this forage.

\section{CONCLUSION}

Bamboo leaves have potential as a forage for ruminants in the highlands of Madagascar. Bamboo leaves are a good source of nitrogen for ruminants and may be complementary to silage in a mixed ration, without compromising the milk production. This allows cows to maintain their performance during the dry season, which is a period of forage shortage. Farmers can integrate bamboo cultivation in their forage system to enhance the feed sufficiency and diversity, in order to improve the animal productivity, as well as the food security. It is important to identify the optimal stage and period to harvest bamboo leaves, in order to reach a moderate fibre content and improve intake and digestibility.

\section{ACKNOWLEDGMENTS}

The authors thank the financial support from the International Network for Bamboo and Rattan (INBAR).

\section{REFERENCES}

ANELE, O. et al. Early growth and seasonal chemical composition of three multipurpose tree species. Agroforestry System, v. 73, n. 2, p. 89-98, 2008.
ANTWI-BOASIKO, C. et al. Proximate composition of the leaves of Bambusa ventricosa, Oxytenanthera abyssinica and two varieties of Bambusa vulgaris. Scientific Research and Essays, v. 6, n. 34, p. 6835-6839, 2011.

ANURUDU, N. F. et al. Reproductive performance of West African Dwarf Ewes fed siam weed-based diets. Tropical Journal of Animal Science, v. 7, n. 1, p. 41-49, 2004.

ASAOLU, V. O. et al. Feed intake, nutrient digestibility and nitrogen utilization of graded levels of moringa and bamboo leaves by West African Dwarf Goats. Bulletin of Animal Health and Production in Africa, v. 57, n. 4, p. 361-368, 2009.

ASSOCIATION OF OFFICIAL ANALYTICAL CHEMISTS (AOAC). Official methods of analysis. 16. ed. Washington, DC: AOAC, 1995.

BERGERET, P. et al. Family farming for enhancing knowledges and human resources. Paris: Presses de Sciences, 2016.

BHANDARI, M. et al. Genetic evaluation of nutritional and fodder quality of different bamboo species. Indian Forester, v. 141, n. 3, p. 265-274, 2015.

BHARDWAJ, D. et al. Nutritive value of introduced bamboo species in the northwestern Himalayas, India. Journal of Forestry Research, v. 2018, p. 1-10, 2018.

CENTRE NATIONAL DE RECHERCHE APPLIQUEE AU DEVELOPPEMENT RURAL (Fofifa). Formation pratique et théorique sur la gestion de la reproduction bovine. Antananarivo: Ministère de l'Agriculture et de l'Elevage de Madagascar, 2018.

DATT, C. et al. Nutritional evaluation of different bamboo leaves of Tripura. Indian Journal of Dairy Science, v. 59, n. 6, p. 376-379, 2006.

DELABY, L.; PEYRAUD, J. Valoriser les fourrages de l'exploitation pour produire du lait. Fourrages, n. 198, p. 191-210, 2009.

FÉRARD, A.; CAREL, Y. Association maïs fourrage: jouer la carte de la complémentarité. Perspectives Agricoles, n. 442, p. 54-57, 2017.

FIOMPIANA FAMBOLENA MALAGASY NORVEZIANA (Fifamanor). Rapport annuel des activités. Antsirabe: Ministère de l'Agriculture de Madagascar, 2009.

FOOD AND AGRICULTURAL ORGANIZATION (FAO). La situation mondiale de l'alimentation et de l'agriculture. 2016. Available at: <http://www.fao.org/3/ai6030f.pdf>. Access on: 16 Aug. 2017.

GAUTHIER, X. Comment les vaches choisiraient-elles leur variété de maïs fourrage. 2016. Available at: < https:// www.arvalisinstitutduvegetal.fr/communique-de-pressecomment-les-vaches-choisiraient-elles-leur-variete-dema-s-fourrage--@/view-1800-arvstatiques.html>. Access on: 15 Aug. 2017. 
GOERING, H.; VAN SOEST, P. Forage fiber analysis. Beltsville: USDA, 1970.

HALVORSON, J. J. et al. Nutritive value of bamboo as browse for livestock. Renewable Agriculture and Food Systems, v. 26, n. 2, p. 161-170, 2010.

HAYASHI, Y. et al. Dairy production and nutritional status of lactating buffalo and cattle in small-scale farms in Terai, Nepal. Livestock Research for Rural Development, v. 17, n. 64 , p. 1-9, 2005.

HUTJENS, M. F. Identifying limiting nutritional constraints to profitability. 1998. Available at: <http://livestocktrail. illinois.edu/dairynet/paperDisplay.cfm?ContentID=242>. Access on: 16 Aug. 2017.

INTERNATIONAL NETWORK FOR BAMBOO AND RATTAN (INBAR). Can bamboo become a year-round crop for animal fodder? 2019. Available at: $<$ https://www. inbar.int/can-bamboo-become-a-year-round-crop-foranimal-fodder/>. Access on: 01 Apr. 2019.

McDONALD, P. et al. Animal nutrition. 7. ed. New Delhi: Prentice Hall, 2010.
NORTON, B. Studies of the nutrition of the Australian goat. 2003. 594 p. Thesis (PhD in Agronomic Science) University of Mebourne, Australia, 2003.

PENOT, E. et al. Adaptability of dairy farms in the highlands of the Vakinankaratra province of Madagascar: impacts of the 2009 crisis. Revue d'Élevage et de Médecine Vétérinaire des Pays Tropicaux, v. 69, n. 1, p. 19-31, 2016.

SHAW, P. Kjeldahl nitrogen analysis. Geneva: WHO, 2006.

TINWORTH, T. et al. The effect of wilting chicory on its voluntary intake and digestion by red deer. Journal of Agriculture Science, v. 133, n. 2, p. 217-221, 1999.

UPRETI, C.; SHRESTHA, B. Nutrient contents of feeds and fodder in Nepal. Gwarko: Nirav, 2006.

VIGNAU-LOUSTAU, L.; HUYGHE, C. Stratégies fourragères: pâturage, ensilage, foin. Paris: France Agricole, 2008.

WORLD BANK. Agriculture \& rural development. 2019. Available at: <https://data.worldbank.org/indicator $>$. Access on: 01 Apr. 2019. 